\title{
ANCIENT EGYPTIAN POTTERY FROM THE SUBSURFACE FLOODPLAIN OF THE SAQQARA-MEMPHIS AREA: ITS MINERALOGICAL AND GEOCHEMICAL IMPLICATIONS*
}

\author{
M. A. HAMDAN,${ }^{1} \dagger$ S. M. MARTINEZ, ${ }^{2}$ M. T. GARCIA VALLÈS, ${ }^{2}$ J. M. NOGUÉS, ${ }^{2}$ \\ F. A. HASSAN,${ }^{3}$ R. J. FLOWER, ${ }^{3}$ M. H. ALY, ${ }^{4}$ A. SENUSSI $^{5}$ and E. S. EBRAHIM ${ }^{1}$ \\ ${ }^{1}$ Geology Department, Faculty of Science, Cairo University, Giza, Egypt \\ ${ }^{2}$ Departament de Cristal.lografia, Mineralogia i Dipòsits Minerals, Universitat de Barcelona, Spain \\ ${ }^{3}$ Department of Geography, University College London, WC1E 6BT, UK \\ ${ }^{4}$ Environmental Studies and Research Institute, Minufiya University, Egypt \\ ${ }^{5}$ Supreme Council of Antiquities (SCA), Egypt
}

\begin{abstract}
Potsherds recovered from the Saqqara-Memphis floodplain in Egypt, dated according to their typology and radiocarbon dating of the included sediments, are analysed geochemically and mineralogically to identify source materials and fabrication characteristics. Pottery layers were identified and potsherds were recovered from several settlement levels. Sherd typology was used to identify sherds from four periods (the Old and New Kingdoms, and from the Late Period to the Ptolemaic). The Pharaonic pieces were found at depths of between 8 and $12 \mathrm{~m}$ and the later material was between 6 and $3 \mathrm{~m}$. Chemical analyses of the potsherds revealed three main source materials: local Nile silt, marl clay and mixed Nile silt-marl. Two marl clay types were recognized: marl clay from Upper Cretaceous marine sediment and another one from Late Pliocene deltaic sediments. The mineralogical composition of the pottery samples shows that the estimated firing temperature was about $850-900^{\circ} \mathrm{C}$. No consistent differences in sherd mineralogy and geochemistry were found according to pottery types, so that the ancient Egyptian potters used essentially the same materials throughout the Pharaonic period. However, this initial study has revealed the existence of extensive pottery-rich occupation sites buried within the Nile floodplain deposits between Memphis and Saqqara.
\end{abstract}

\section{KEYWORDS: POTTERY, ANCIENT EGYPTIAN, MINERALOGY, GEOCHEMISTRY, SAQQARA, MEMPHIS}

\section{INTRODUCTION}

The River Nile floodplain has been populated since at least the beginning of the third millennium BC. Unfortunately, our knowledge of Egyptian settlements in the area south of the Delta is generally limited. However, settlements are known to be located on the floodplain, with a preference for proximity to a Nile channel for irrigation, securement of water and for transportation of goods by boat. Shifts in the course of the channel, build-up of the Nile floodplain by annual silt deposition and the impact of high Nile floods have led to complexities in depositional environments.

Sherds and other artefacts located within the sediment stratigraphies of such deposits can reveal much about the location of occupation sites, and they can help establish a depositional history relevant to human activities and landscape changes. Much remains to be learned about the significance of buried settlements in the Nile Valley floodplains (Hassan 1997). The SaqqaraMemphis area was the location of the ancient Egyptian capital after state unification (3000 BC)

\footnotetext{
*Received 9 January 2013; accepted 4 June 2013

$\dagger$ Corresponding author: email hamdanmohamed@hotmail.com

(C) 2013 University of Oxford
} 
and once established Memphis was either the capital city or an important political centre until early Roman times (Jeffreys 2000). The area is archaeologically rich but, beyond the royal necropolis and temple complex of Saqqara and Memphis itself, the region is poorly explored. As part of ongoing geoarchaeological investigations, a series of sediment cores was collected from the floodplain between Saqqara and Memphis to explore the distribution of sediment types and the provenance of archaeological material, notably potsherds.

The coring sites were primarily positioned to explore the geomorphological development of the River Nile and its implications for human activity in this region of ancient Egypt. Some of the cores revealed large amounts of archaeological material (Hamdan 2010). In this study, the provenance and composition of this archaeological material, notably potsherds, was investigated in relation to sediment stratigraphy. This work was undertaken with the aim of not only revealing the distribution of buried ancient potsherds between Saqqara and Memphis, but also to characterize pottery production in the region. The mineralogical and geochemical composition of the recovered pottery was also studied to identify different topologies and to characterize the raw materials of fabrication, so that both manufacturing processes and source materials could be identified and placed in a chronological sequence. Because the floodplain region between Saqqara and Memphis is so poorly known, the use of large-diameter augur coring was selected as the most appropriate method of exploring the area by enabling relatively rapid sampling over a relatively large area $\left(20 \mathrm{~km}^{2}\right)$.

\section{THE GEOLOGICAL SETTING}

The studied pottery was collected at different depths in the floodplain sediments of the SaqqaraMemphis area (about $30 \mathrm{~km}$ south of Cairo). The geological setting of the Saqqara area has been intensively investigated (e.g., Said 1975, 1990; Yehia 1985; Moustafa 1988; Hamdan 2000). From a geomorphological point of view, the area is subdivided into three units (Fig. 1 (a)): (1) The Nile floodplain; (2) The Limestone Plateau (30-80 $\mathrm{m}$ above the neighbouring Nile floodplain); and (3) the cuesta scarp, which lies at the eastern edge of the limestone plateau. The limestone plateau is dissected by two significant drainage channels (wadis), passing from the desert area on either side of the Saqqara pyramid to the floodplain.

The oldest exposed strata in the Saqqara area are Upper Eocene marly shale beds with some gypsum streaks. This unit is capped by the upper calcareous layers of the Saqqara Member (Yehia 1985), and is overlain by a thick, laminated alternating succession of light yellow, hard limestone and softer yellow marl, which constitutes the bulk of the Saqqara-Abu Sir Plateau. At the top of the succession, there is a unit of sandy to marly limestone and shales. A small exposure of Late Pliocene (Helwan Formation; Said 1975, 1990) shale and fine-grained sandstone also occurs. The Quaternary sediments are represented by several fluvial terraces, which consist of sand and gravel with thin layers of old Nile silt (Hamdan 2000).

\section{MATERIALS}

The present study is based on 33 potsherds, which were recovered from five large-diameter $(37 \mathrm{~cm})$ auger cores of up to $19 \mathrm{~m}$ long from five locations in the floodplain between Saqqara and Memphis (Fig. 1 (a) and Table 1). We also used six soil samples corresponding to the proposed raw materials; four samples representing Nile silt were collected from core SAQA22, from depths of $140 \mathrm{~cm}, 320 \mathrm{~cm}, 920 \mathrm{~cm}$ and $1020 \mathrm{~cm}$, corresponding to samples N-1 to N-4, respectively (Fig. 1 (b)). Two samples corresponding to desert marl clay raw materials were collected 
(a)

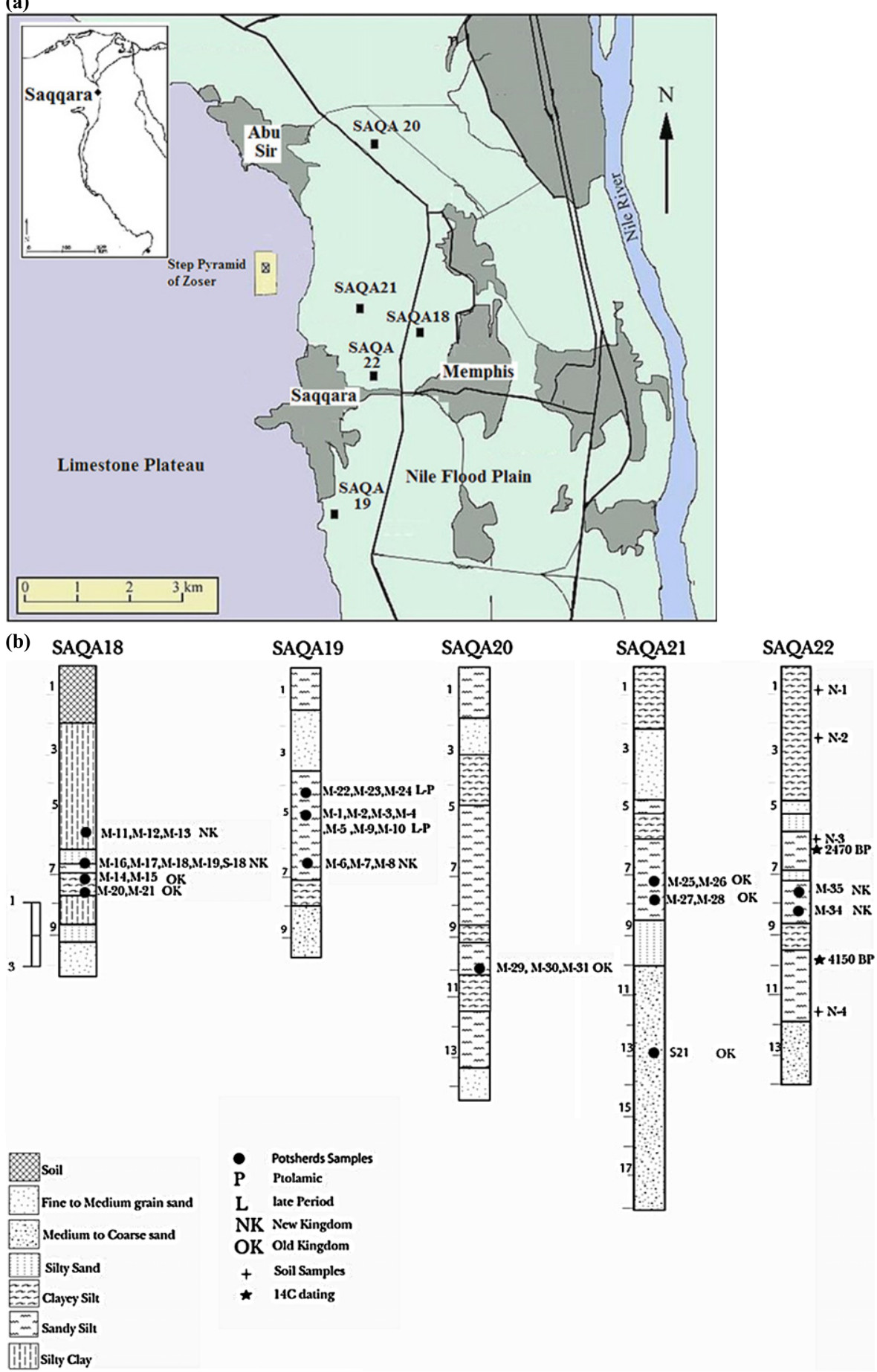

Figure 1 (a) A location map of the studied cores, which shows the main geomorphic units, modern villages and roads. (b) The detailed lithological characteristics of the Saqqara-Memphis cores, with their locations, depths and the chronology of the studied potsherds. 
M. A. Hamdan et al.

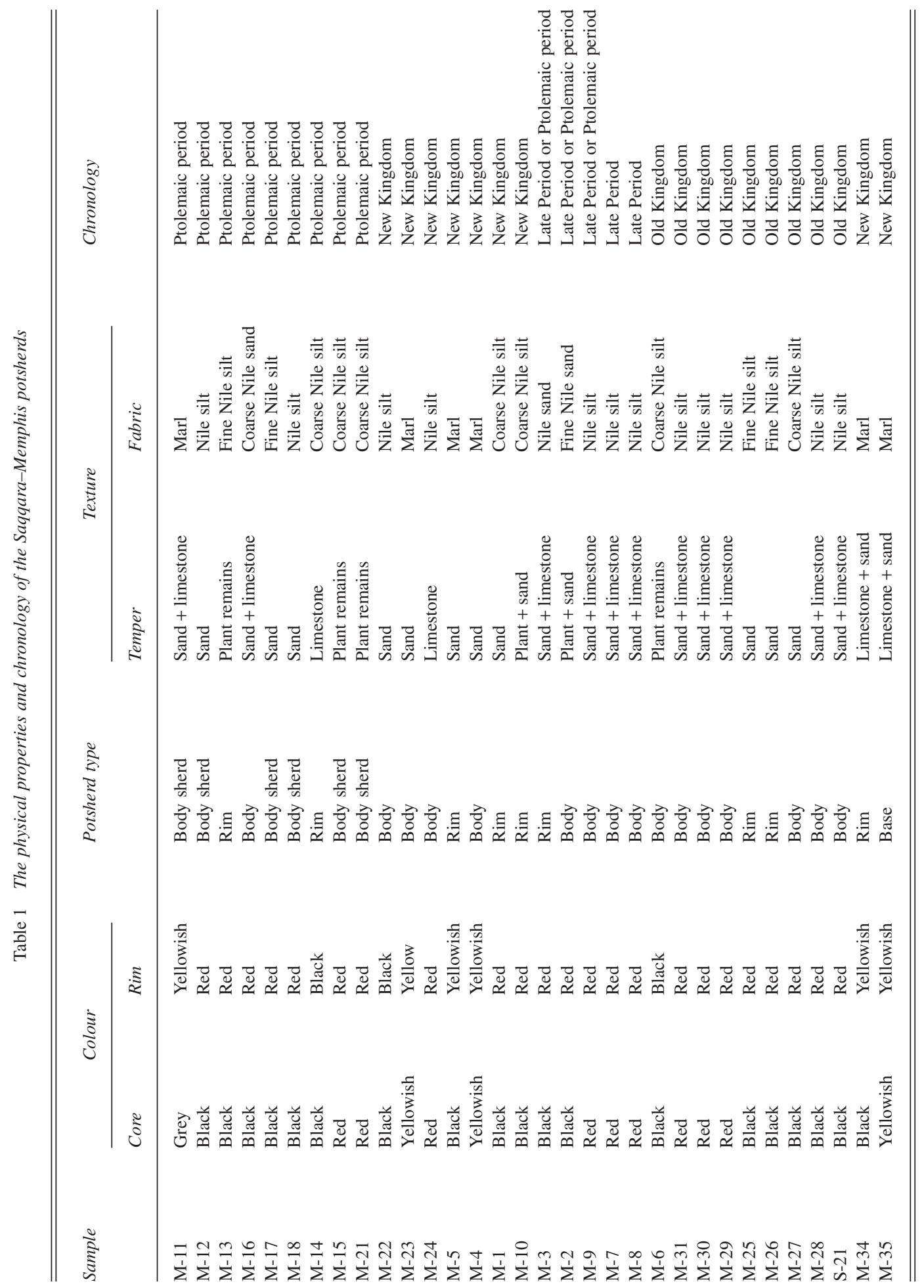

(c) 2013 University of Oxford, Archaeometry ••, ••(2013) ••_•• 
from the Qena area (D-1) and the Pliocene Helwan Formation from the north-west Saqqara area (D-2). A detailed geological description of the studied cores as well as of the depths of the recovered potsherds is shown in Figure 1 (b). The main lithologies of these cores are characterized by floodplain silts with thin intercalations of channel sand, levée and crevasse sandy silt.

\section{METHODOLOGIES}

Pottery samples were studied in the laboratory using a binocular microscope (Nikon SMZ-500) to identify their textures and to make a macroscopic characterization. The samples were also embedded in resin for polarizing light microscopy (Nikon Eclipse LV100pol).

Fragments of each sample were also prepared for study by X-ray fluorescence (XRF), X-ray diffraction (XRD) and scanning electron microscopy (with microanalysis, SEM-EDAX). Analyses of sample compositions were undertaken by XRF, using a Phillips PW 2400 sequential X-ray spectrophotometer. Analysis of major elements was undertaken using fused pearls (lithium tetraborate pearls at a dilution of 1/20), three for each sample. Trace elements were determined on pressed powder pellets.

Mineralogical characterization of pressed powder samples was made by XRD, using an automatic analytical X'Pert system. Diffraction patterns in the $4-100^{\circ} 2 \theta$ range were obtained with a $0.017^{\circ} 2 \theta$ step scan and a $2 \mathrm{~s}$ counting time. The operating conditions were $45 \mathrm{kV}$ and $40 \mathrm{~mA}$, using $\mathrm{Cu}-\mathrm{K}_{\alpha}$ radiation (1.54061 $\AA$ ) and a graphite monochromator. Analytical software packages ('X'Pert Graphics' and 'Identify', by Philips) were used on diagnostic peaks and semi-quantified mineral phases.

The microtextural and semi-quantitative chemistry of individual phases were examined using a JEOL JSM-840 and ESEM Quanta 200 FEI, XTE 325/D8395 SEM. The working conditions were $10 \mathrm{kV}$ and $3 \times 10^{-9} \mathrm{~A}$, and $20 \mathrm{kV}$ and $1 \times 10^{-9} \mathrm{~A}$, respectively. Samples were mounted on stubs and covered with graphite prior to microanalysis by energy-dispersive X-ray spectrometry (EDS).

\section{RESULTS AND DISCUSSION}

\section{Chronology}

The depth, colour, temper type, fabric and chronology of the studied sherds are shown in Table 1. The chronology of the sherds is based on two sources: ${ }^{14} \mathrm{C}$ dating of two soil samples from core SAQA22 [2470 $\pm 40 \mathrm{cal}$ BP (Beta - 246002) and $3860 \pm 40 \mathrm{cal} \mathrm{BP}($ Beta - Beta - 242117) at depths of 7.5 and $10.5 \mathrm{~m}$ below the surface, respectively] and the typological determination. On the basis of these two sources, the studied sherds are dated to the Old and New Kingdom as well as to the Late Period and the Ptolemaic. The latter is represented by nine samples from core SAQA19, while three Old Kingdom sherds were recovered from core SAQA20. New Kingdom sherds are represented by 10 sherds from core SAQA18; three sherds from core SAQA21, from depths of 7-8 m; and two sherds from core SAQA22.

\section{Pottery typology}

In general, pottery recovered from the studied cores included well-known types from contemporary Saqqara and Memphis archaeological sites. Core SAQA18 contained potsherds at four depths 5.5-6.1, 6.4-6.6, 6.6-6.8 and 7.5-7.7 $\mathrm{m}$ below the floodplain surface (Table 1 and Fig. 1 (b)). Typologically, almost all the pottery sherds are made of Nile silt and some of them are 
clearly related to Egyptian brown amphorae, which, at the Saqqara-Memphis archaeological sites, are dated to the Ptolemaic period (e.g., Bourriau and Aston 1985). Pottery sherds in core SAQA19 were recovered at three levels; 3.7-4.7, 4.7-5.1 and 6.6-6.7 $\mathrm{m}$ below the floodplain surface, and all dated from the Ptolemaic period to the New Kingdom. The first level yielded five body sherds of plain Nile silt ware and one of Egyptian yellow marl ware. In the second level, 17 body sherds of Nile silt ware were recovered, along with 10 sherds of hard yellow Egyptian marl ware. The lower pottery level contained eight body sherds of Nile silt and two rim sherds of a plain bowl or cup. The diagnostic sherds in this level are simple rims of round-based bowls.

In core SAQA21, potsherds were recovered from three levels, 7.0-7.3, 7.3-8.0 and 12.65$13.35 \mathrm{~m}$ below the surface and dated to the Fourth or Fifth Dynasties (Hawass and Senussi 2008). The first level includes: 10 body sherds of roughly made Nile silt bread moulds; nine of Nile silt red slipped ware; one body sherd of a roughly made traditional offering jar (beer jar) with orange slip; it also comprises one rim sherd of a flat-based bowl with flaring sides; one rim sherd of a conical bread mould; three flat-based oval bases from bread moulds; and a rim sherd of a conical bread mould (Arnold and Bourriau 1993). The second level yielded the following sherd types: eight body sherds of plain Nile silt ware; seven of roughly made bread moulds; one of fine hard Nile silt (possibly part of a recurved rim bowl); two rim sherds of a short carinated recurved rim bowl (called Meydum bowls: Petrie 1909); and two rim sherds of a short carinated recurved rim bowl (Hawass and Senussi 2008). The third pottery level contained: eight body sherds of Nile silt burnished red; one rim sherd of an inner-thickened bowl; 20 tiny body sherds of coarse Nile silt; and many thick-walled bread mould sherds, probably part of an early wide-mouth bread mould (Hawass and Senussi 2008).

In core SAQA22, two pottery levels were recorded, at 6.95-7.59 and 7.59-7.95 m below the floodplain surface and mainly dated to the New Kingdom. The former is represented by four body sherds of coarse Nile silt, five of plain red Nile silt, five of Egyptian pink marl ware, four of fine grey marl ware, and four rim sherds and one ring base sherd. The second pottery level contained two body sherds of coarse Nile silt, eight of plain red Nile silt, two of Egyptian pink marl ware and four sherds of fine grey marl ware.

\section{Physical properties}

Most recovered sherds are not homogeneous in colour but typically have a black central part, with red externally. However, some sherds are homogeneously red in colour (sample M-26; core SAQA21) or black (e.g., sample M-1; core SAQA19). Marl ware sherds usually exhibit a homogeneous yellowish-grey or cream colour (e.g., samples M-34 and 35; core SAQA22). The cream colour of this pottery is due to the incorporation of iron in the structure of the calcium silicates and to less extensive development of the iron oxides (Maniatis et al. 1983). As is well established, differences in the colour of the samples are due to the different firing atmospheres and their influence on colour. Chemical composition and mineralogy also plays a certain role (Wakamatsu et al. 1985; Abdrakhimov and Abdrakhimova 1999; Maritan et al. 2006). The greys and blacks involve reducing atmospheres, with a reduction of iron $\left(\mathrm{Fe}^{3+}\right)$ oxides in magnetite, in partial reduction of $\mathrm{Fe}^{3+}$ to $\mathrm{Fe}^{2+}$. The different sequences in the colours mean different cycles in the atmosphere of the furnace. For example, a red-grey-red sequence involves firing in an oxidizing atmosphere, a reduction at high temperature and a final high-temperature oxidation, which gives it the red colour outside, leaving a black heart inside. The relative intensity of the bands depends on the time and intensity of the oxidation and reduction to which the pieces are submitted. 
In the studied samples, we have the following sequence: (a) pink-red in the external part of the piece and grey-black in the internal part; (b) red-black-red; and (c) black. In case (a), the grey colour dominates almost the entire piece except for the red outer layer; this means that was fired in a reducing atmosphere with partial reduction of $\mathrm{Fe}^{3+}$ to $\mathrm{Fe}^{2+}$, while the red layer indicates a subsequent external oxidation, while maintaining a certain reduction inside the piece. The problem is to determine whether the reducing atmosphere is voluntary, either casual or feature firing with firewood. The possibility of it resulting from the subsequent use of pottery for cooking is not very credible, as the temperatures are lower than can be achieved in a wood fire and the container usually contains more liquid, the temperature being determined by the boiling water. Case (b) is similar to (a), but in this case it is oxidized both on the interior and on the outside, showing that the interior of the piece had good access to the oxidizing atmosphere of the furnace. Finally, in case (c), the black pottery is completely reduced, indicating that the reducing environment was maintained throughout the period of firing of the piece.

Some of the sherds are porous, rough and with a coarse fabric, and others show a fine fabric (e.g., M-2; core SAQA19). Sand (quartz) temper is most common in the studied sherds. Some sherds exhibit mixed sand-limestone temper (e.g., M-12 and 14; core SAQA18) or sand-straw temper (e.g., M-15; core SAQA18). A few sherds are tempered only by different plant remains and animal dung (e.g., sample M-4; core SAQA19). Grog-tempered sherds are represented only by sample M-5, from core SAQA19. When straw temper and other organic materials burn out during firing, they leave voids and vugs, and these help to prevent the propagation of large cracks, allowing the fabric to heat quickly, as the porosity improves the thermal shock resistance (Vila and Planell 1991). Also, these voids allow the pottery to 'sweat', so that evaporation can keep stored water in the vessel cool and fresh (Nicholson 2009).

\section{CHEMICAL COMPOSITION}

\section{Major elements}

The major elemental composition of the studied sherds and the proposed raw materials (Table 2) is used in multivariate statistical analysis to group samples according to their chemical composition (data were re-normalized to give equal weight to the widely varying concentrations). The cluster analysis dendrogram differentiates four groups. The first two groups are separated by: (a) a high $\mathrm{CaO}$ content, 12.75-18.55\% (samples M-4, M-5, M-23, M-34 and M-35); and (b) a high $\mathrm{Al}_{2} \mathrm{O}_{3}$ content, 18.33-20.16\% (samples M-3, M-13 and M-18). The third group is separated by a high $\mathrm{Al}_{2} \mathrm{O}_{3}(14.40-16.58 \%)$ and a relatively lower $\mathrm{SiO}_{2}$ content (58.22-63.30\%) and comprises samples M-1, M-7, M-9, M-8, M-17, M-14, M-24, M-2, M-6 and M-22. The fourth group consists of samples M-10, M-21, M-30, M-15, M-31, S-18, S-21, M-11, M-12, M-25, M-16, M-27, M-26, M-29 and M-28, with $\mathrm{Al}_{2} \mathrm{O}_{3}$ values ranging from 10.69 to $15.26 \%$ and an $\mathrm{SiO}_{2}$ content between 62.08 and $72.41 \%$.

The elemental fingerprints of the raw material sources of the potsherds were shown (Fig. 2) by utilizing the $\mathrm{SiO}_{2} / \mathrm{Al}_{2} \mathrm{O}_{3}$ ratio versus the ratio of the transition element oxides $(\mathrm{Fe}+\mathrm{Mn}+\mathrm{Ti})$ to the alkali oxides $(\mathrm{Ca}+\mathrm{Mg}+\mathrm{Na}+\mathrm{K})$. Silica and aluminium are the major elements forming minerals in Egyptian pottery (Redmount and Morgenstein 1996). The transition elements are derived from heavy mineral grains, heavy mineral inclusions in quartz, and weathered products such as hematite and associated iron oxy-hydroxides that are responsible for colouring the pottery. The alkali metals are modifiers of the silica-aluminium mineral complexes 
M. A. Hamdan et al.

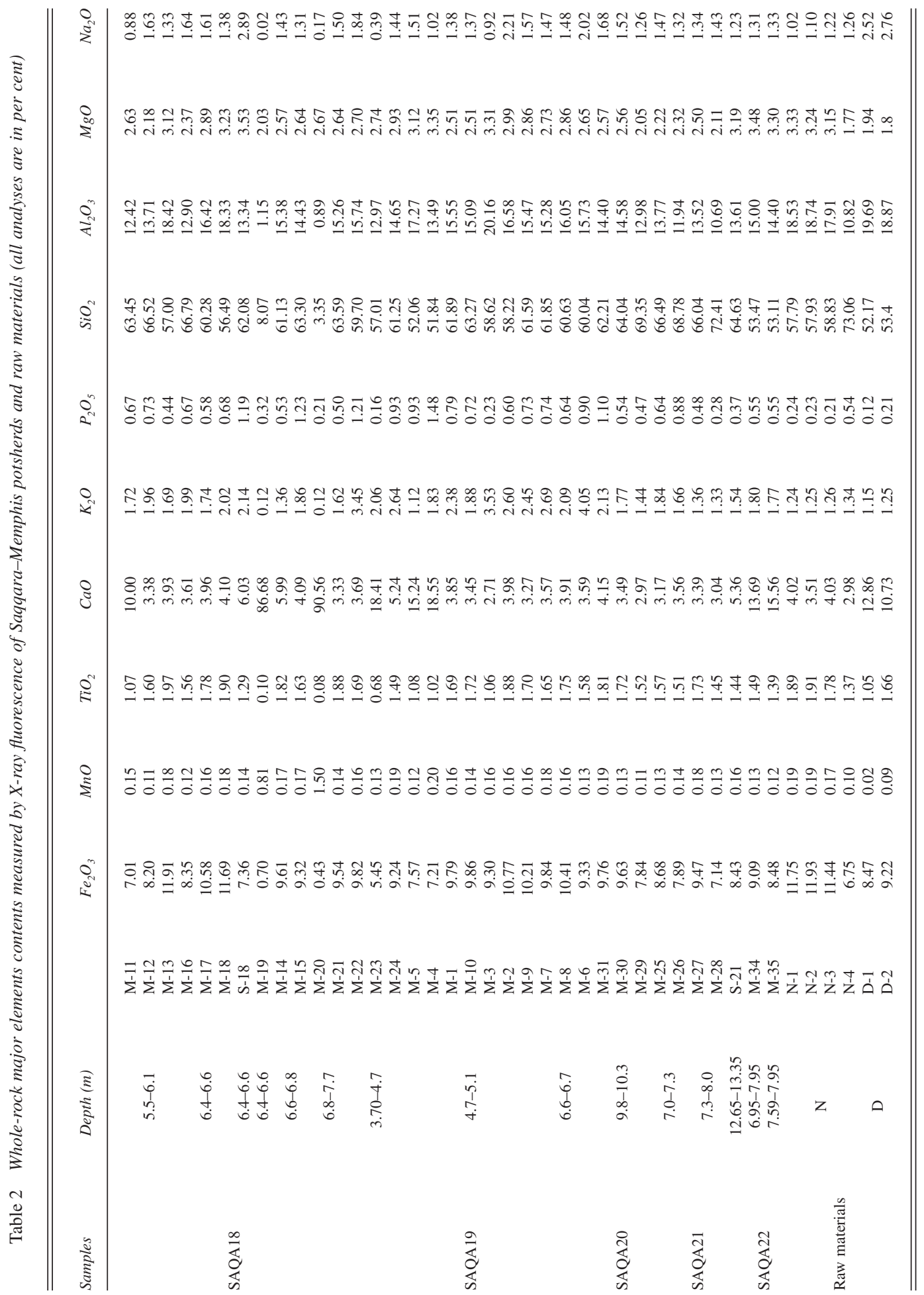

() 2013 University of Oxford, Archaeometry ••, •• (2013) ••-•• 


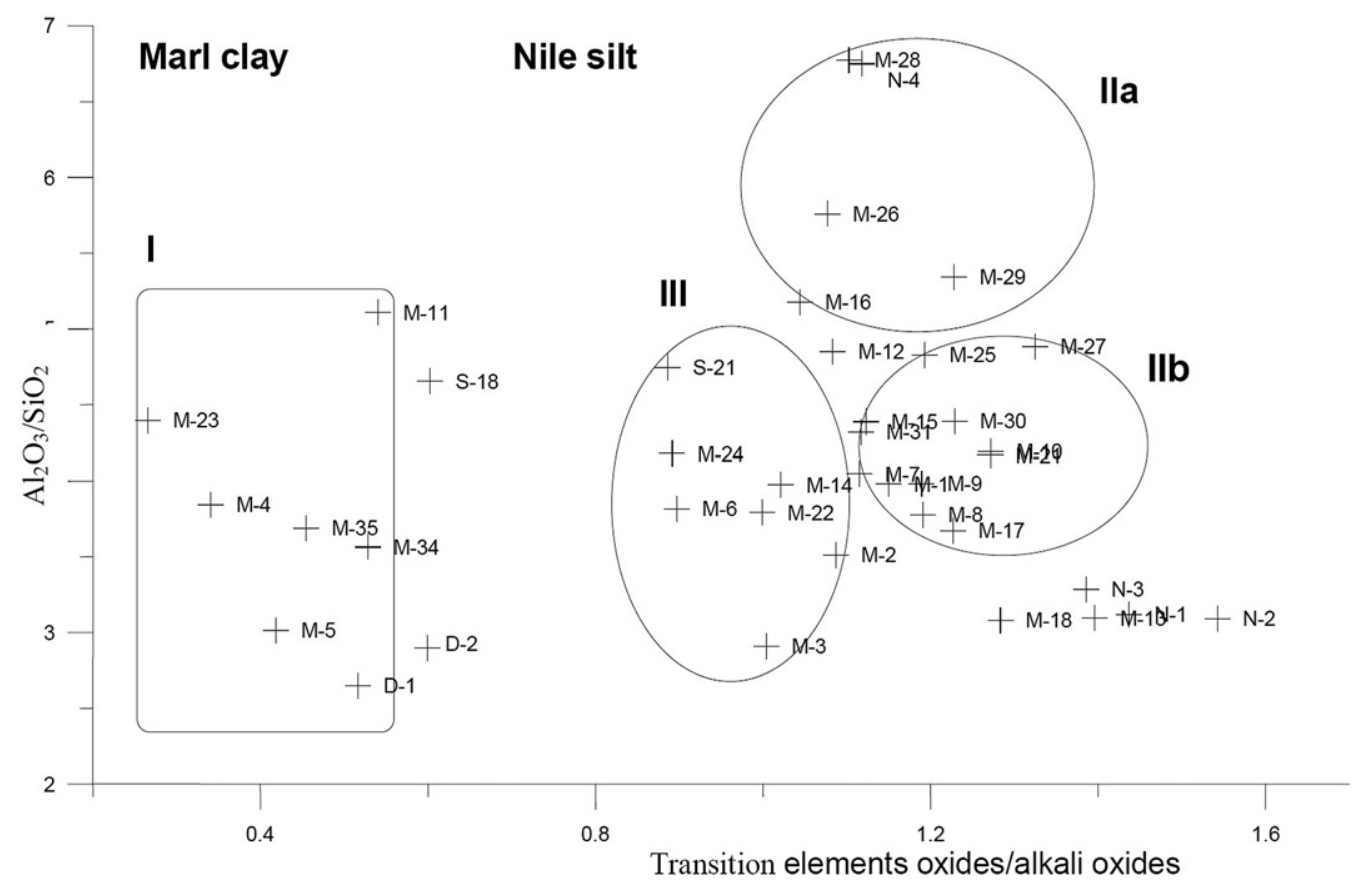

Figure 2 A scattergram showing the relationship between the major elements oxide ratios from Table 2: transition element oxides $=\mathrm{Fe}_{2} \mathrm{O}_{3}+\mathrm{MnO}+\mathrm{TiO}$ and alkali oxides $=\mathrm{CaO}+\mathrm{MgO}+\mathrm{Na}_{2} \mathrm{O}+\mathrm{K}_{2} \mathrm{O}$.

(exchangeable cations in clays). They are also very important in marl clay sediments, as they are element formers with carbonates (Redmount and Morgenstein 1996).

Three raw material categories are clearly discriminated (Fig. 2): marl clay, Nile silt and mixed raw materials. The latter category (III) is mainly Nile silt mixed with carbonate or proper Nile silt with limestone temper. Marl clay (I) is plotted according to the low transition element to alkali ratio; Nile silt shows higher ratios of transition element to alkali $(>1)$. Nile silts could be discriminated into two subcategories (IIa and IIb), according to the $\mathrm{SiO}_{2} / \mathrm{Al}_{2} \mathrm{O}_{3}$ ratio, therefore subcategory (IIa) has high $\mathrm{SiO}_{2} / \mathrm{Al}_{2} \mathrm{O}_{3}$ ratios (>5\%) and subcategory (IIb) has high transition element to alkali ratios. This discrimination is also best shown on the $\mathrm{CaO} / \mathrm{Al}_{2} \mathrm{O}_{3}$ versus $\mathrm{SiO}_{2} /$ $\mathrm{Al}_{2} \mathrm{O}_{3}$ scattergram: whereas samples M-11 and S-18 were difficult to differentiate in Figure 2, they are clearly discriminated in Figure 3. The parent sources of the minerals present in Nile silts are granitic and basaltic igneous rocks associated with the White and Blue Nile highlands (Central Africa and Ethiopia, respectively). Subcategory IIa is characterized by a high silica content and subcategory IIb (pottery clay of basaltic origin) is always characterized by relatively low silica and high transition element oxides.

The plot of $\mathrm{CaO} / \mathrm{Al}_{2} \mathrm{O}_{3}$ versus $\mathrm{Fe}_{2} \mathrm{O}_{3} / \mathrm{Al}_{2} \mathrm{O}_{3}$ (Fig. 3) discriminates two marl clay raw materials (Ia and Ib), corresponding to the iron oxide content. Marl clay (Ia), with less $\mathrm{Fe}_{2} \mathrm{O}_{3} / \mathrm{Al}_{2} \mathrm{O}_{3}$, is probably related to Pliocene clay (Helwan Formation; Said 1990), which is exposed to the west of the Saqqara region (Hamdan 2000). The second marl clay (Ib), with a high $\mathrm{Fe}_{2} \mathrm{O}_{3} / \mathrm{Al}_{2} \mathrm{O}_{3}$ content, probably represents ware imported to the Saqqara-Memphis area. It seems that the Eocene rocks in the nearby escarpments are represented mainly by limestone and marls with a 


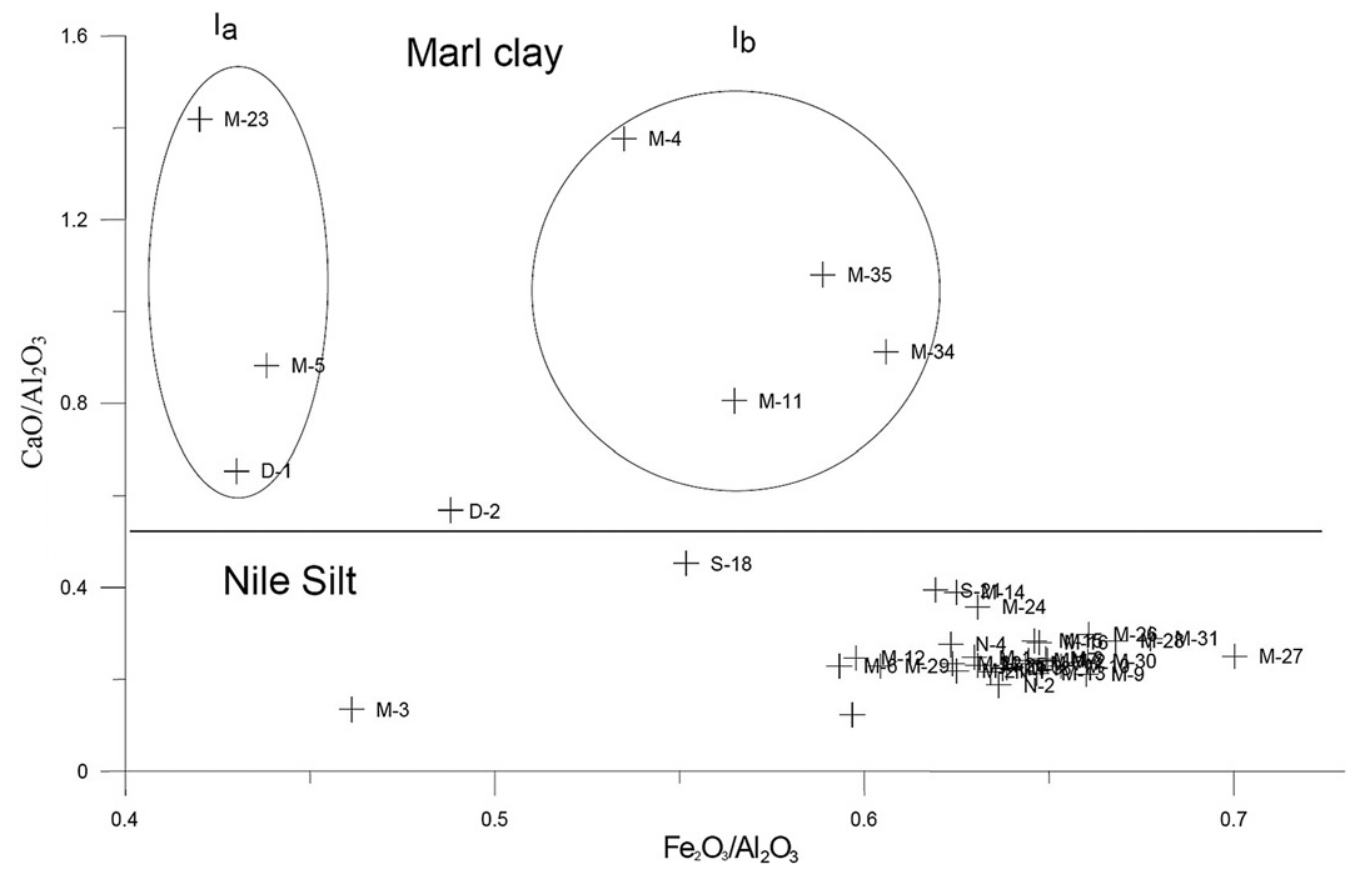

Figure 3 A scattergram of the $\mathrm{CaO} / \mathrm{Al}_{2} \mathrm{O}_{3}$ ratio versus the $\mathrm{Fe}_{2} \mathrm{O}_{3} / \mathrm{Al}_{2} \mathrm{O}_{3}$ ratio, to discriminate the two marl clay groups (Ia and $\mathrm{Ib}$ ) from the Nile silt raw materials.

low clay content (Said 1975). In fact, the typical marl clay suitable for pottery production is generally limited in Egypt and confined mainly to the area around Qena, Upper Egypt (Arnold and Bourriau 1993).

The iron oxide versus titanium oxide plot shows a strong correlation between oxides of iron and titanium, and indicates a genetic relationship between the two elements. In the Nile silt, iron is present as an oxidized/hydrated mineral phase, generally as a component of the clay-size fraction (goethite, hematite and magnetite). Iron also occurs in heavy detrital minerals such as magnetite that are in the silt fraction of Nile alluvium and sediments derived from volcanics (Morgenstein and Redmount 2005). Titanium is rich in heavy mineral grains such as titanomagnetite, ilmenite and titano-augite. The minerals ilmenite and hematite are also likely to be intergrown, and during weathering may form oxy-hydroxides in the sediments (Hamroush 1986; Allen et al. 1989). Figure 4 also shows two line fits: the marl clays have a good regression sum of squares $\left(R^{2}=0.977\right)$, corresponding to a similar origin; and the Nile silts have a poor regression sum of squares $\left(R^{2}=0.508\right)$, related to a more dispersed origin of the raw materials of the samples.

Pottery phosphate could be used to investigate the potential for pottery fingerprinting. Pottery phosphate is derived from soil minerals, from organic sources (such as dung and other fecal debris, straw and chaff) and from orthophosphatic organic acid complexes on mineral grains (from dissolved constituents in sediment pore water; Mallory-Greenough et al. 1998). On the $\mathrm{SiO}_{2} / \mathrm{Al}_{2} \mathrm{O}_{3}$ versus $\mathrm{P}_{2} \mathrm{O}_{5}$ diagram, the marl clay samples are scattered in several fields corresponding to the phosphate content. The highest $\mathrm{P}_{2} \mathrm{O}_{5}$ contents in all samples are those of the marl ware sample (M-4) and Nile silt ware sample (M-5). The raw material samples were generally poor in $\mathrm{P}_{2} \mathrm{O}_{5}$ content, except for sample (N-2) $0.23 \%$. A high phosphate content is probably due to 


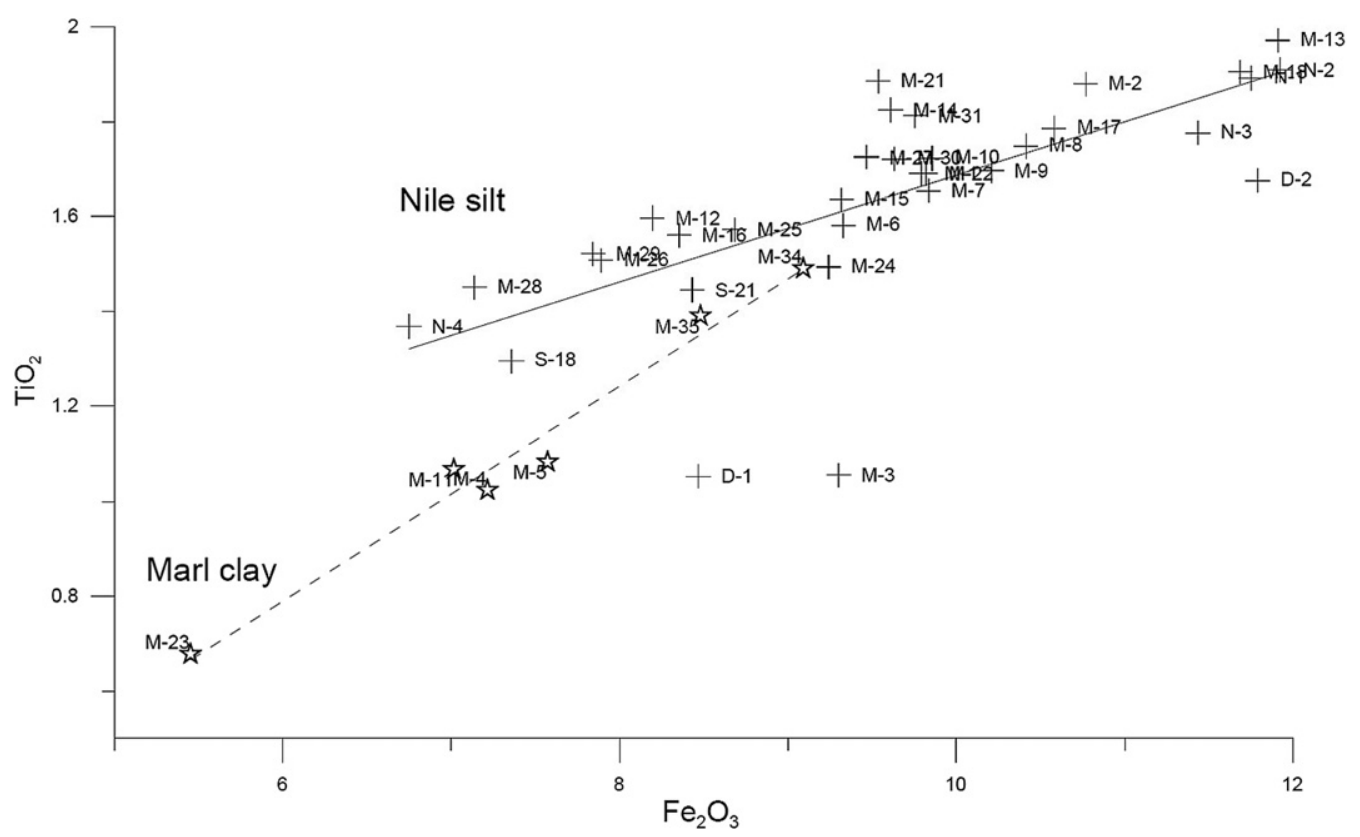

Figure 4 A scattergram of the iron oxide versus titanium oxide contents of the studied potsherds.

addition of organic temper (such as dung and other fecal debris, straw and chaff) or is possibly inherited in the raw material, which could be derived from older archeological settlements (anthrosols). Anthrosols associated with cultural activities at the archaeological site are rich in organic detritus, bone and humus, which are rich in phosphate content.

Some limestone-tempered sherds (e.g., samples S-18 and M-2) contain relatively higher $\mathrm{Na}_{2} \mathrm{O}$ contents (2.89 and $2.21 \%$, respectively) than the remaining samples. A high $\mathrm{Na}_{2} \mathrm{O}$ content is probably related to salt added to the pottery paste or to the use of salty water in pottery manufacture. Sodium in potsherds may also be related to the ash of burnt straw temper or natron (sodium carbonate). The addition of salt to calcareous material in pottery apparently retards calcination of calcium carbonates to beyond $1000^{\circ} \mathrm{C}$, and prevents the formation of calcium hydroxide $(\mathrm{CaOH})$ when water is present with $\mathrm{CaCO}_{3}$ (Stimmell 1978). Calcium hydroxide is detrimental to pottery because it is volumetrically greater than the original $\mathrm{CaCO}_{3}$ and $\mathrm{H}_{2} \mathrm{O}$ and so weakens the product, leading to rapid deterioration and failure of the pottery material (Mann 1986).

\section{Trace elements}

Discrimination between different raw materials is also indicated by using binary plots of both major elements and trace elements (Figs 5 (a) and (b); see also Table 3); for example, calcium oxide versus strontium, calcium oxide versus thorium, calcium oxide versus nickel, and iron oxide versus thorium. Almost all samples, except for sample $\mathrm{M}-23(\mathrm{Sr} / \mathrm{Ca}=0.0548)$, show the same $\mathrm{Ca} / \mathrm{Sr}$ ratio (Fig. 5 (a)). The sum of squares $\left(R^{2}=0.83\right)$ regression of these data indicates similar environmental conditions of carbonate formation. Sample M-23 contains a higher carbonate content, probably due to the existence of an external patina of bone powder. Both $\mathrm{CaO}$ 


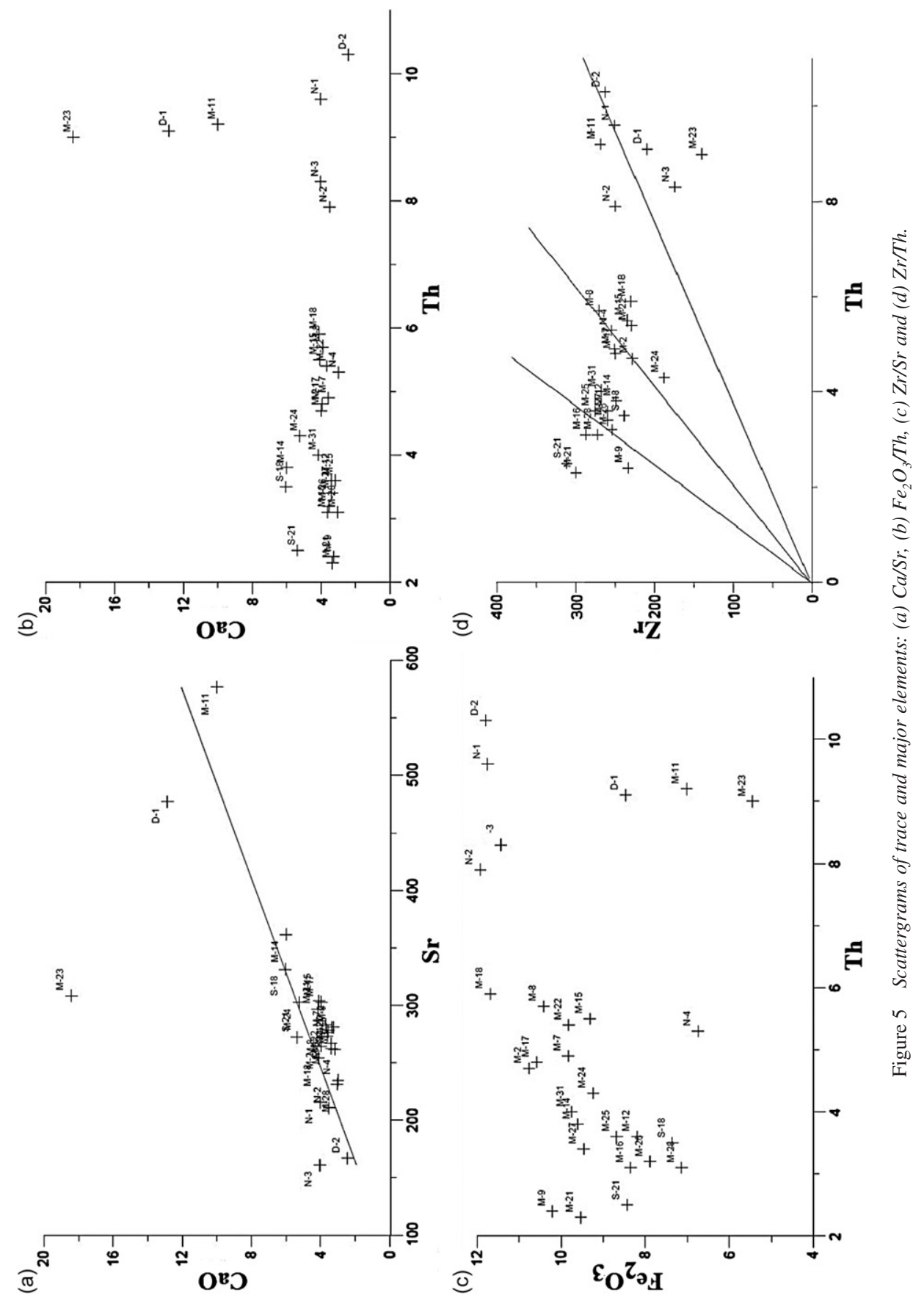




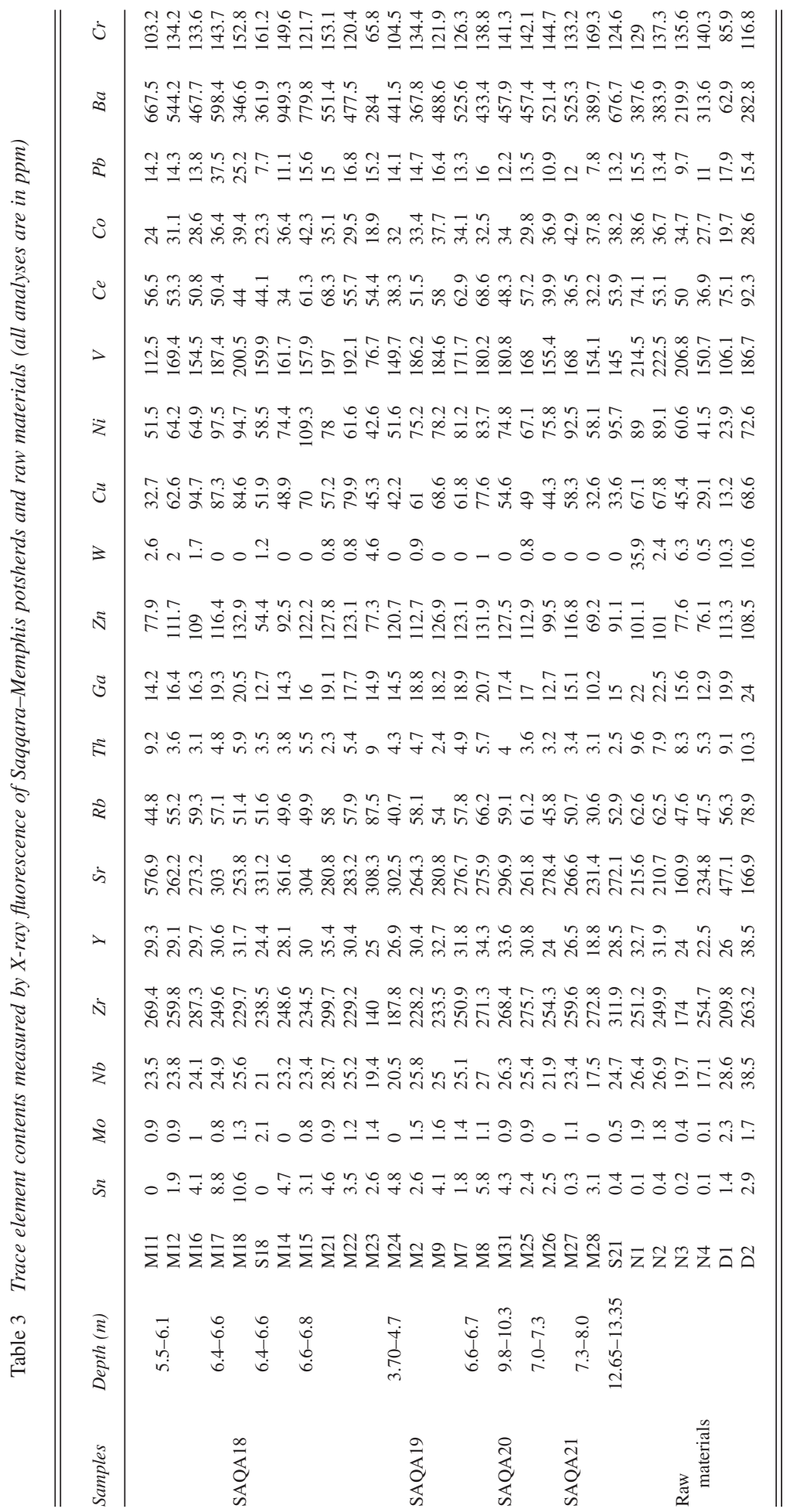


and $\mathrm{Sr}$ are enriched in marl clay raw materials (e.g., samples M-11 and M-23). The results for mixed and Nile silt raw materials plot within one field with low contents of $\mathrm{Ca}$ and $\mathrm{Sr}$ (the main group). Sample M-23 has a similar Sr content to the main group, but with a high Ca content.

The marl clay raw materials (samples M-23 and M-11) are discriminated from the Nile silts and mixed raw materials. The Nile silt samples could be discriminated into two groups of similar calcium content, but with different thorium content. The iron versus thorium plot (Fig. 5 (b)) shows good discrimination between different samples of Nile silts, depending on the thorium content. The Nile silt of Ethiopian origin is plotted within one large field with high iron and low thorium. The Nile silts of central African origin (e.g., samples M-22, M-26 and M-28) are plotted in a distinct field with relatively low iron and high thorium. The marl clay samples (M-11 and M-23) are plotted in a separate field with low iron and high thorium. The mixed raw materials (e.g., M-8, M-22 and M-15) are plotted between the Nile silt and marl clay raw materials.

Trace elements such as $\mathrm{Ba}, \mathrm{Sr}, \mathrm{Rb}, \mathrm{Zr}$ and $\mathrm{Th}$ are also usual for fingerprinting raw materials. Several scattergram plots of trace elements (Figs 5 (c) and 5 (d)) show a clear separation between a particular Nile silt source area and the overall field of Nile silts. However, the Nile silts are the most problematic category for resolution, as they are geochemically very similar to each other. The $\mathrm{Sr} / \mathrm{Cr}, \mathrm{Sr} / \mathrm{Zr}$ and $\mathrm{Sr} / \mathrm{Rb}$ ratios (Fig. 5 (c)), indicate that all samples (excluding M-23 and M-11) have a similar composition.

On the $\mathrm{Zr}$ versus Th scattergram (Fig. 5 (d)), samples are discriminated into three groups: the first includes soil materials (excepting N4) and the samples M-11 and M-23; the second group consists of samples M-2, M-7, M-8, M-15, M-17, M-18, M-22, M-24 and N4 (soil sample), and the third group is that of samples M-9, M-12, M-14, M-16, M-21, M-25, M-26, M-27, M-28, M-31, S-18 and S-21. These groups are also discriminated by the same samples on the $\mathrm{CaO}$ versus Th plot and are related to different temper components. Samples M-21 and S-21 are more enriched in $\mathrm{Zr}$ than the other Nile silt wares. The high $\mathrm{Zr}$ content in the Nile silt indicates the encroachment of aeolian sand (from the Western Desert) into floodplain silts, or that aeolian sand was added as a temper.

The marl clay sources (samples M-11 and 23) are also discriminated using $\mathrm{Sr}$ versus $\mathrm{Rb}$ and $\mathrm{Sr}$ versus $\mathrm{Ba}$ relationships, corresponding to the $\mathrm{Rb}$ and $\mathrm{Ba}$ contents, respectively. The scattergram of $\mathrm{Cr}$ versus $\mathrm{Ni}$ clearly discriminates the different types of Nile silts, which are plotted in several fields corresponding to the Ni content. The two marl samples (M-11 and M-23) plot within a low-Cr and -Ni field.

\section{MINERAL COMPOSITION AND FIRING TEMPERATURE}

\section{Petrographic characteristics}

Microscopically, the studied potsherds consist of a paste matrix with different percentages of lithoclasts, crystalloclasts, bioclasts and ceramoclasts (grog). The matrix has a sintered, microcrystalline-amorphous to microcrystalline-vitreous and low porous character. The clayey matrix is mostly dark brown or reddish-yellow, with a few samples showing greyish-brown shades. Clastic particles, in general comprising between 6 and 15\% of the total, are generally angular to sub-angular (Fig. 6 (a)). The lithoclasts, crystalloclasts, bioclasts and ceramoclasts have a variable composition, depending mainly on the clay raw material and the temper. Lithoclasts are represented mainly by limestone fragments, added as temper. The crystalloclasts are represented by quartz grains (both monocrystalline and polycrystalline; Fig. 6 (b)), plagioclase and potassium feldspar, as well as micas (Fig. 6 (c)). Different types of vegetal 

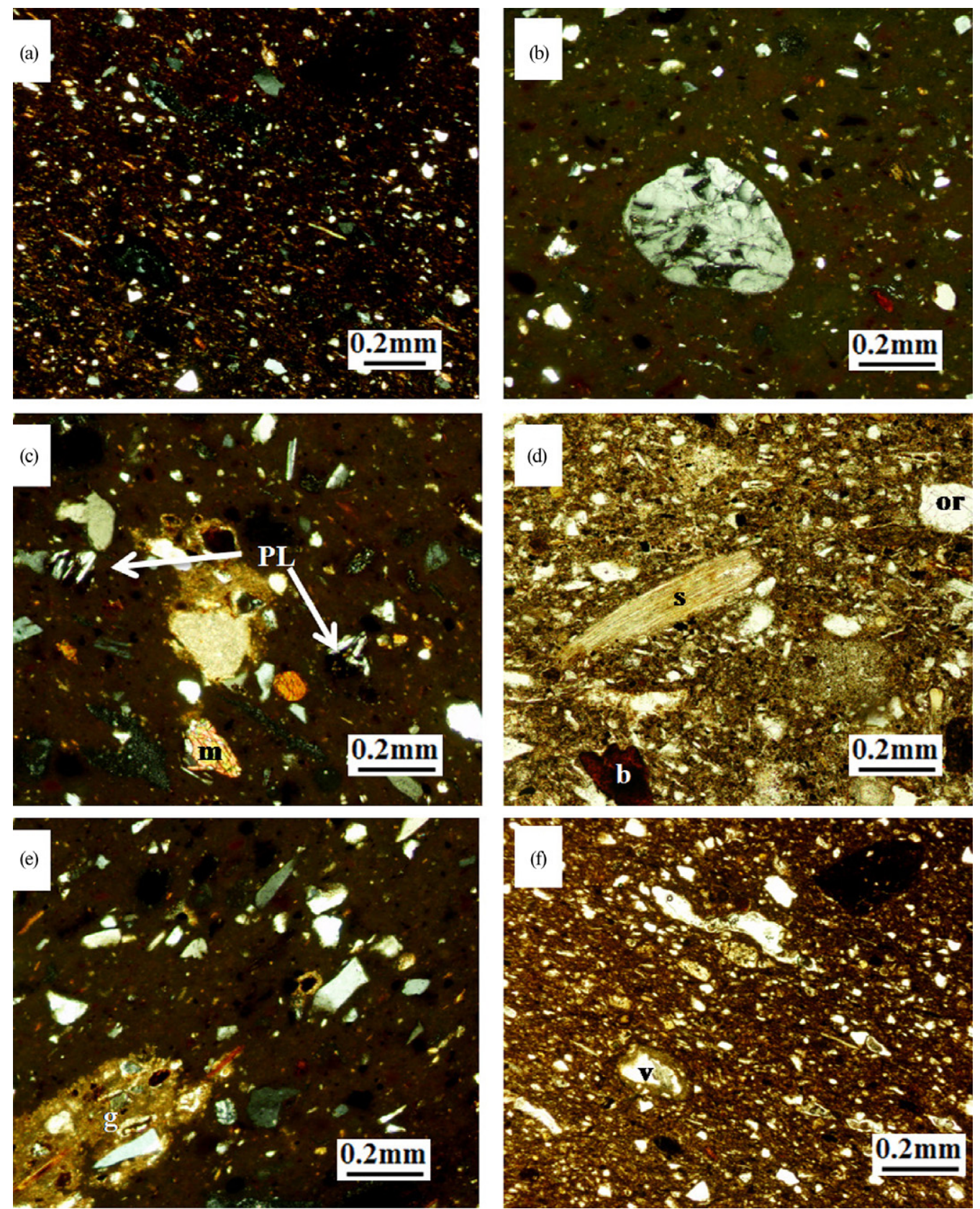

Figure 6 Photomicrographs of the Saqqara-Memphis potsherds: (a) sample M-3 angular to sub-angular clastic temper, crossed nicols; (b) sample M-5, poly-crystalline quartz grain, crossed nicols; (c) sample M-4, plagioclase (PL) and muscovite ( $m$ ), crossed nicols; (d) sample M-1, straw temper ( $s)$ and orthoclase grain (or), plane-polarized sample; (e) M-4 grog temper $(g)$, crossed nicols; $(f)$ sample $M-1$, vugs and cavities $(V)$ and carbonate grains, plane-polarized. 
remains, such as straw (Fig. 6 (d)), leaves and stem fragments, are recognized as bioclasts. A few shell fragments and a little dung are also recognized in several sherds. Ceramoclasts (grog) are recorded in a few studied sherds (Fig. 6 (e)). Sample (M-2) contains micrite and calcium oxide film-coated bubble vugs (Fig. 6 (f)) that commonly occur in a mix of raw material (Nile silt and marl clay). The vugs are likely to be formed during firing and appear to be derived from the degassing (the loss of carbon dioxide) of carbonate limestone grains of the temper.

\section{XRD analysis}

The main mineral constituents of the studied potsherds (Table 4 (a)) are quartz, K-feldspar and plagioclases, with minor phases of diopside, gehlenite, calcite and hematite. Ilmenite, hercynite, illite and gypsum are occasionally recorded. In the pottery paste (Table 4 (b)), quartz, feldspars and a lower proportion of hematite are the common mineral phases; another group found in variable proportions is pyroxene. Calcite is recorded only in samples D-1 and D-2. Two samples contain gehlenite (samples M-4 and M-23). Gypsum is attributed to secondary processes and is not in the original composition of the pottery paste. Plagioclase is most probably related to the original composition of the clay paste, but in some cases, where the firing temperature was higher, may have been formed during firing. This may explain the broad dispersion of plagioclase content in the studied samples.

Firing temperatures of ancient pottery are of major interest because they provide information on the performance of the bonfire-kilns used and on the firing behaviour of the potters (Schiffer 1976; Baba 2009). Traditional studies of firing temperatures estimate the firing temperature through the study of either the minerals or the newly formed mineral phases, which result from the firing process by means of X-ray diffraction and thermal analysis, as well as by petrological examination.

The mineralogical composition of the sherds (Table 4 and Fig. 7) allows estimation of the firing temperatures; for example, where samples have a low illite content, this may indicate that they were subjected to a firing temperature above about $900^{\circ} \mathrm{C}$ (illite disappears at $950^{\circ} \mathrm{C}$; Heimann 1982). Two samples (M-4 and M-23) collected from the same core SAQA19 (Figs 1 (a) and 1 (b)) contain gehlenite $\left(\mathrm{Ca}_{2} \mathrm{Al}_{2} \mathrm{SiO}_{7}\right)$, indicating a firing temperature of over $850^{\circ} \mathrm{C}$. Sample M-23 contains less calcite than it should have according to its bulk composition, and also contains diopside $\left(\mathrm{CaMgSi}_{2} \mathrm{O}_{6}\right)$ and gehlenite $\left(\mathrm{Ca}_{2} \mathrm{Al}_{2} \mathrm{SiO}_{7}\right)$, pointing to a firing temperature around $900^{\circ} \mathrm{C}$. The presence of calcite in the sherds is considered as a contamination in the paste or as a nodule of carbonate not destroyed on the kiln. Calcite could be considered as a re-carbonated $\mathrm{CaO}$ nodule, since calcite starts its decomposition at approximately $880^{\circ} \mathrm{C}$, when it converts to the oxide, liberating $\mathrm{CO}_{2}$ (Eiland and Williams 2000). Gehlenite and pyroxene are neoformed mineral phases caused by destruction of calcium carbonate; accordingly, the typical firing temperature indicated ranges from 850 to $900^{\circ} \mathrm{C}$.

\section{Surface coatings}

The pottery surface may be entirely coated for decoration or to reduce permeability. There are two main kinds of pottery coatings: (1) clay-rich coatings and (2) glassy coatings (glaze). Depending on their permeability, clay-rich coatings can be subdivided into two types: permeable and impermeable slip.

Permeable slip is generally opaque and porous and does not undergo major modifications during firing (Memmi Turbanti 2004). Permeable slip is generally either red or white, and red slip 
Table 4 Mineralogical compositions, using the semi-quantitative X-ray diffraction technique (a) Saqqara-Memphis pottery*

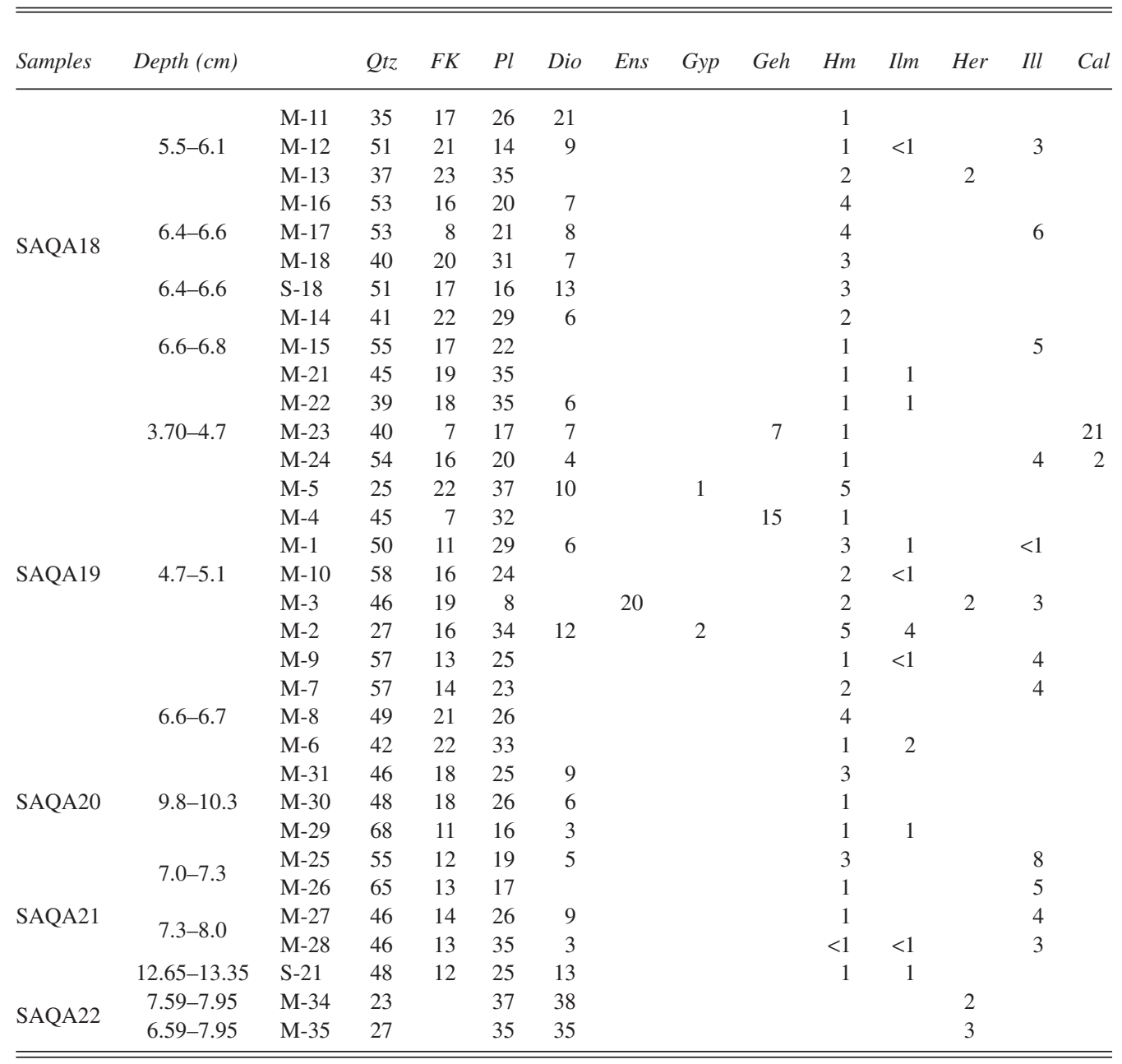

*Qtz, quartz; Fk, K-feldspar; Pl, plagioclase; Dio, diopside; Ens, enstaite; Gyp, gypsum; Geh, gehlenite; Hm, hematite; Ilm, ilmanite; Her, hercynite; Ill, illite; Cal, calcite.

(b) The proposed raw materials*

\begin{tabular}{|c|c|c|c|c|c|c|c|c|}
\hline & Quartz & Plagioclase & Nontronite & Kaolinite & Calcite & Aragonite & Sepiolite & Palygorskite \\
\hline N-1 & +++ & +++ & ++ & + & & & & \\
\hline $\mathrm{N}-2$ & +++ & + & + & $\operatorname{tr}$ & & & & \\
\hline $\mathrm{N}-3$ & +++ & ++ & + & $\operatorname{tr}$ & & & & \\
\hline $\mathrm{N}-4$ & +++ & + & $\operatorname{tr}$ & $\operatorname{tr}$ & & & & \\
\hline D-1 & +++ & + & & + & ++ & ++ & & \\
\hline D-2 & +++ & ++ & & + & + & + & & \\
\hline
\end{tabular}

*N, Nile silt; D, desert marl clay. +++, Rich; ++, abundant; +, few; tr, traces. 

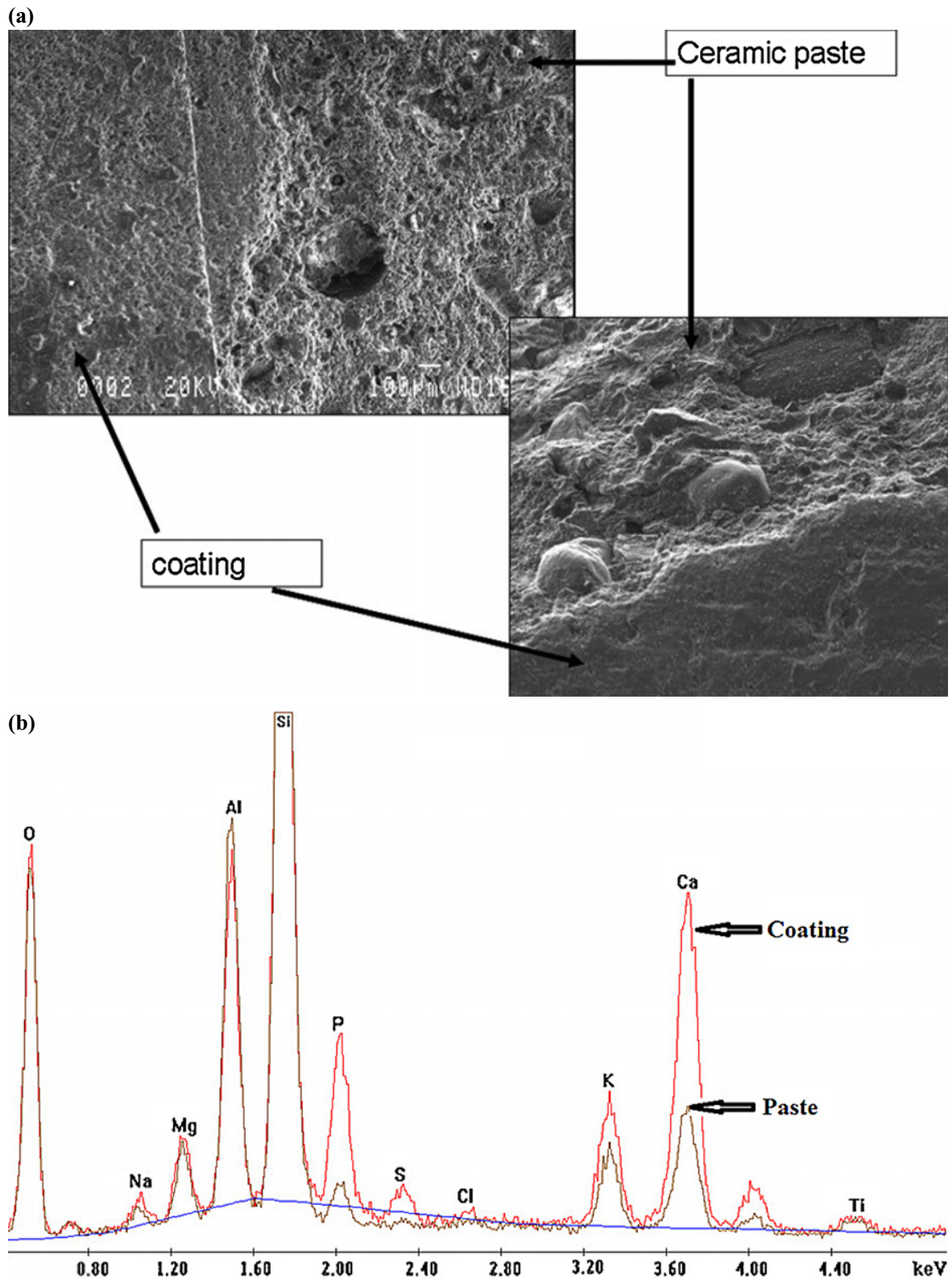

Figure 7 SEM micrographs of the coating and the ceramic paste, and the EDAX pattern.

is obtained from a clay rich in iron oxide (up to $15 \mathrm{wt} \%$ ) and fired under generally oxidizing conditions. White slip usually consists of kaolinite-rich clay or a clay with very low iron content (Memmi Turbanti 2004). Some potsherds (samples M-23, 24 and M-14, Table 5) contain permeable red slip on their external sides, probably used for decoration purposes. SEM imagery of 
Table 5 The $\mathrm{CaO}$ and $\mathrm{P}_{2} \mathrm{O}_{5}$ contents of the coating layer $(C)$ and the potsherds paste $(P)$ of three samples $(M-11,23$ and 24)

\begin{tabular}{lcccrcrrr}
\hline \hline Sample & $\mathrm{Al}_{2} \mathrm{O}_{5}$ & $\mathrm{SiO}_{2}$ & $\mathrm{SO}_{3}$ & $\mathrm{Fe}_{2} \mathrm{O}_{3}$ & $\mathrm{P}_{2} \mathrm{O}_{5}$ & $\mathrm{CaO}$ & $\mathrm{CaO}_{2} \mathrm{O}_{5}$ & $\mathrm{TCP}$ \\
\hline $\mathrm{M}-11 \mathrm{C}$ & 11.95 & 36.11 & 0.25 & 9.38 & 9.88 & 26.83 & 2.72 & 1.19 \\
$\mathrm{M}-11 \mathrm{C}$ & 12.27 & 48.58 & 0.00 & 10.92 & 2.32 & 19.72 & 8.50 & 7.30 \\
$\mathrm{M}-11 \mathrm{P}$ & 13.94 & 49.26 & 0.29 & 12.38 & 0.76 & 16.19 & 21.30 \\
$\mathrm{M}-23 \mathrm{C}$ & 12.73 & 51.31 & 0.52 & 7.03 & 2.6 & 18.94 & 17.28 & 48.00 \\
$\mathrm{M}-23 \mathrm{P}$ & 14.07 & 55.06 & 0.45 & 6.31 & 0.36 & 14.84 & 1.56 \\
$\mathrm{M}-24 \mathrm{C}$ & 12.21 & 43.09 & 1.64 & 8.66 & 9.51 & 5.33 & 3.70 \\
$\mathrm{M}-24 \mathrm{P}$ & 16.68 & 54.26 & 0.00 & 12.55 & 1.44 & & \\
\hline \hline
\end{tabular}

the studied sherds clearly shows the presence of surface coatings of impermeable slip, and that these slip layers are darker in colour and finer in texture than the original paste (Fig. 7 (a)).

The $\mathrm{CaO}$ and $\mathrm{P}_{2} \mathrm{O}_{5}$ contents of the coating layer $(\mathrm{C})$ and the paste $(\mathrm{P})$ of three potsherds (samples M-11, 23 and 24) are cited (Table 5 and Fig. 7 (b)). The EDAX chart (Fig. 7 (b)) shows that the coating layer is richer in both $\mathrm{CaO}$ and $\mathrm{P}_{2} \mathrm{O}_{5}$ than the pottery paste in three studied samples. A close similarity of the $\mathrm{CaO} / \mathrm{P}_{2} \mathrm{O}_{5}$ ratios is detected (Table 5) in the coating layers, as is tricalcium phosphate (TCP). The tricalcium phosphate phase corresponds to calcinate hydroxyapatite, which exists in animal bones.

\section{CONCLUSIONS}

Potsherds were recovered from five sediment cores (3.5-12.5 m long) taken below the floodplain surface in the Saqqara-Memphis area. Sherd typology was used to attribute the samples to Old Kingdom (2700-2184 вC), New Kingdom (1570-1070 вC) and Late Period to Ptolemaic (747$732 \mathrm{BC}$ ) dates. The majority of the studied potsherds had a rough and coarse fabric, tempered with quartz sand, mixed with limestone fragments and straw, and were most probably used in settlements. In general, the studied potsherds included well-known types similar to those recovered from the Saqqara and Memphis archaeological sites. The predominant types are bread moulds and beer jars in the Old Kingdom layers and round-based bowls and storage pots in New Kingdom ones.

Major and trace element analyses reveal three main raw materials (Table 6), as follows. (i) Nile silt was exploited locally from the floodplain and mainly represents two sources. Holocene Nile silt from Ethiopian sources is characterized by chemically high transitional element oxides (Fe, $\mathrm{Ti}$ and $\mathrm{Mn}$ ), $\mathrm{Cr}$ and $\mathrm{Ni}$, and relatively low alkali oxides ( $\mathrm{Ca}, \mathrm{Na}$ and $\mathrm{Ka}$ ), $\mathrm{Th}, \mathrm{Sr}$ and $\mathrm{Zr}$. The second Nile silt is probably older (Late Pleistocene) and is derived from central African sources. It is richer in silica and alkali oxides, as well as in $\mathrm{Th}, \mathrm{Sr}$ and $\mathrm{Zr}$, than the Ethiopian material. (ii) The marl clay raw materials comprise two types: desert marl ' $I$ ', which is mainly derived from the Middle Eocene marl of Upper Egypt and is characterized by higher contents of $\mathrm{CaO}, \mathrm{Fe}_{2} \mathrm{O}_{3}$, $\mathrm{MnO}, \mathrm{TiO} \mathrm{Zr}, \mathrm{Sr}, \mathrm{Ba}$ and $\mathrm{Cr}$ and low Rb. Marl type 'II' has comparatively lower values and seems to be derived locally from the Late Pliocene-Holocene Formation (Table 6). (iii) The mixed Nile silt and marl clay shows geochemical similarities in both major and trace elements to the Nile silt of Ethiopian sources, but with a relatively higher $\mathrm{CaO}$ content (Tables 2 and 5). The main minerals determined are quartz, K-feldspar and plagioclases; minor phases are diopside, enstatite, gehlenite, calcite and hematite, and occasionally ilmenite, hercynite, illite and gypsum. The mineralogical composition of the sherds reflects a firing temperature ranging from 850 to $900^{\circ} \mathrm{C}$. 
M. A. Hamdan et al.

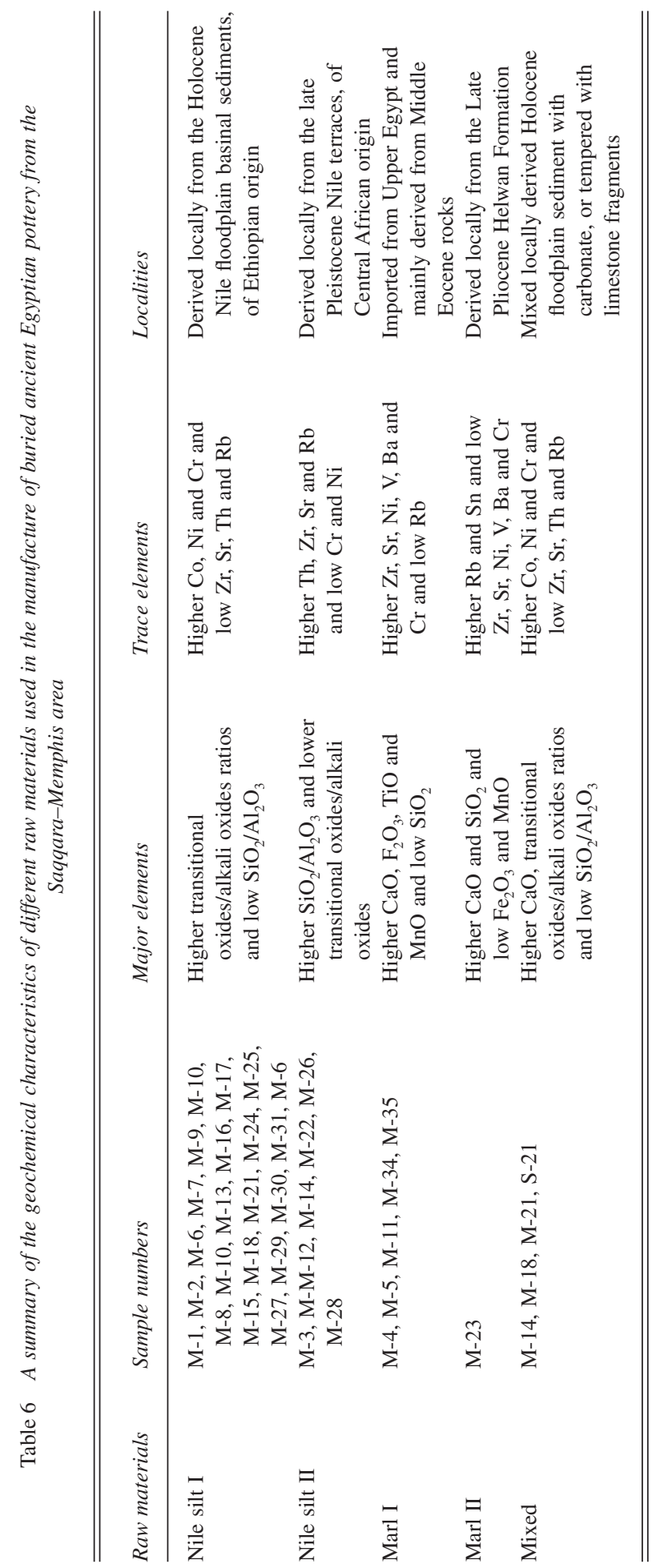

(c) 2013 University of Oxford, Archaeometry ••, ••(2013) ••_•• 
The manufacture of some sherds involved the use of a technology that is more sophisticated than that of the other ceramics studied. They are covered by a thin layer of different composition and texture compared to the paste. This research has attempted to shed more light on the pottery of ancient Egyptian settlements buried under Nile flood sediments. Not only does potsherd analysis help identify manufacturing characteristics and source materials, but it also contributes to our understanding of sediment stratigraphy in the Saqqara-Memphis region.

\section{ACKNOWLEDGEMENTS}

We are grateful for a grant (code LRG-45605) from the British Council to F. Hassan and R. Flower, which funded the core drilling, the sediment analyses and the ${ }^{14} \mathrm{C}$-dating of the charcoal samples. The XRD, XRF and EDAX analyses of the Saqqara-Memphis potsherds were carried out at the laboratories of the Departament de Cristal.lografia, Mineralogia i Dipòsits Minerals of the Universitat de Barcelona, Spain. The authors also acknowledge the efforts of Professor Aleya Havez of Cairo University, who kindly revised the manuscript.

\section{REFERENCES}

Abdrakhimov, V. Z., and Abdrakhimova, E. C., 1999, Formation of the black core in high-speed firing of floor tiles, Glass and Ceramics, 56(7-8), 30-2.

Allen, R. O., Hamroush, H., and Hoffman, M. A., 1989, Archaeological implications of differences in the composition of Nile sediments, in Archaeological chemistry IV (ed. R. O. Allen), 33-56, Advances in Chemistry Series 220, American Chemical Society, Washington, DC.

Arnold, D., and Bourriau, J. (eds.), 1993, An introduction to ancient Egyptian pottery, Philipp von Zabern, Mainz am Rhein.

Baba, M., 2009, Pottery production at Hierakonpolis during the Naqada II period: toward a reconstruction of the firing technique, 1-23, British Museum Studies in Ancient Egypt and Sudan 13, The British Museum, London.

Bourriau, J., and Aston, D., 1985, The pottery, in The tomb-chapels of Paser and Ra'ia at Saqqâra (ed. G. T. Martin), Egypt Exploration Society, London.

Eiland, M. L., and Williams, Q., 2000, Infra-red spectroscopy of pottery from Tell Brak, Syria, Journal of Archaeological Science, 27, 993-1006.

Hamdan, M. A., 2000, Subsurface late Pleistocene Nile flood plain sediments of Saqqara area: paleoenvironmental interpretations, Journal of Sedimentology of Egypt, 8, 243-54.

Hamdan, M. A., 2010, Nile behavior during First Intermediate Period (2185-2000 BC), in 10th International Conference of Geology of Arab World (GAW10), Cairo University, Abstract, 154.

Hamroush, H., 1986, Geoarchaeology: Egyptian predynastic ceramics and geochemistry, Episodes, 9, 160-5.

Hassan, F. A., 1997, Climate, famine and chaos: Nile floods and political disorder in early Egypt, in Third millennium BC climate change and old world collapse (eds. H. N. Dalfes, G. Kukla and H. Weiss), 1-23, Springer-Verlag, Berlin.

Hawass, Z., and Senussi, A., 2008, Old Kingdom pottery from Giza, Supreme Council of Antiquities, Cairo.

Heimann, R., 1982, Firing technologies and their possible assessment by modern analytical methods, in Archaeological ceramics (eds. J. S. Olin and A. D. Franklin), 89-96, Smithsonian Institution Press, Washington, DC.

Jeffreys, D., 2000, Investigating ancient Memphis, Pharaonic Egypt's northern capital, Archaeology International, 3, 24-7.

Mallory-Greenough, L. M., Greenough, J. D., and Owen, J. V., 1998, Provenance of a New Kingdom Egyptian pottery sherd: evidence from the petrology and mineralogy of basaltic temper, Geoarchaeology: An International Journal, 13, 391-410.

Maniatis, Y., Simopoulos, A., Perdikatsis, V., and Kostikas, A., 1983, The effect of reducing atmosphere on minerals and iron oxides developed in fired clays, Journal of the American Ceramic Society, 66, 773-81.

Mann, J., 1986, Composition and origin of material in pre-Columbian pottery, San Salvador Island, Bahamas, Geoarchaeology: An International Journal, 1(2), 183-94.

Maritan, L., Nodari, L., Mazzoli, C., Milano, A., and Russo, U., 2006, Influence of firing conditions on ceramic products: experimental study on clay rich in organic matter, Applied Clay Science, 31(1), 1-15. 
Memmi Turbanti, I., 2004, Pottery production and distribution: the contribution of mineralogical and petrographical methodologies in Italy, Periodico di Mineralogia, 73, 239-57.

Morgenstein, M. E., and Redmount, C. A., 2005, Using portable energy dispersive fluorescence (EDXRF) analysis for on-site study of pottery sherds at El Hibeh, Egypt, Journal of Archaeological Science, 32, 1613-23.

Moustafa, A., 1988, Wrench tectonics in the northwestern desert of Egypt (Abu-Raoash area, southwest of Cairo), 1-16, Scientific Research Series, 2, Middle East Research Center, Ain Shams University, Egypt.

Nicholson, P. T., 2009, Pottery production, in UCLA Encyclopedia of Egyptology (ed. W. Wendrich), Los Angeles, http://escholarship.org/uc/item/1nq7k84p (accessed 9 December 2013).

Petrie, W. M. F., 1909, Meydum and Memphis III, School of Archaeology in Egypt, University College London.

Redmount, C. A., and Morgenstein, M. E., 1996, Major and trace element analysis of modern Egyptian pottery, Journal of Archaeological Science, 23, 741-62.

Said, R., 1975, Subsurface geology of Cairo area, Memoires de l'Institut d'Egypte, tome soixante, Cairo.

Said, R., 1990, The geology of Egypt, A. A. Balkema, Rotterdam.

Schiffer, M. B., 1976, Behavioral archaeology, Academic Press, New York.

Stimmell, C., 1978, A preliminary report on the use of salt in shell tempered pottery of the Upper Mississippi Valley, Wisconsin Archeologist, 69, 266-74.

Vila, M. M., and Planell, J. J., 1991, Propagación de grietas por fatiga en cementos oseos acrilicos, Anales de Mecánica de la Fractura, 8, 124-8.

Wakamatsu, M., Takeuchi, N., Maung, O., Ishida, S., and Imai, K., 1985, Influence of kiln atmosphere on color and sintering properties of red clay containing iron, Yogyo Kyokaishi, 93(7), 349-56.

Yehia, A., 1985, Geological structures of the Giza pyramids plateau, 100-20, Scientific Research Series, 5, Middle East Research Center, Ain Shams University, Egypt. 